\title{
Model Proses Bisnis
}

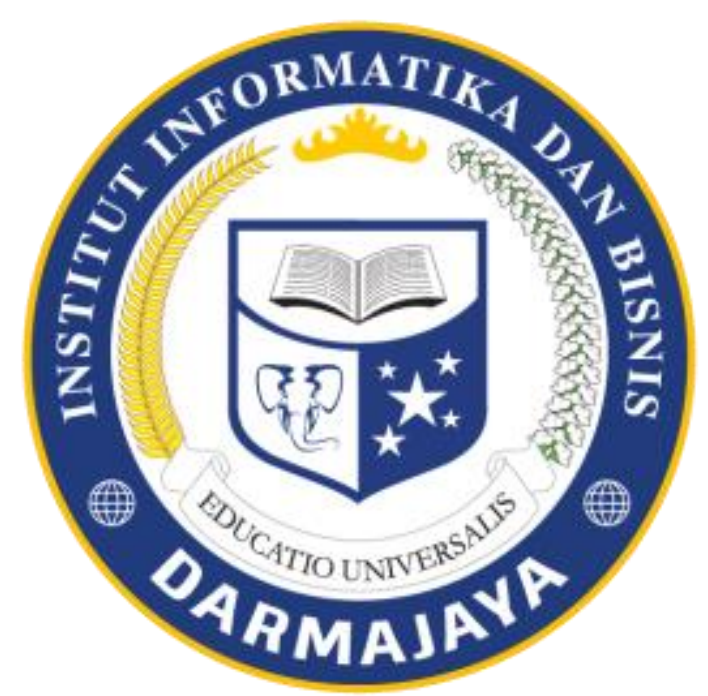

\author{
Sovi \\ 1711050049
}

Prodi Sistem Informasi

Fakultas Ilmu Komputer

INSTITUT INFORMATIKA \& BISNIS DARMAJAYA T.A 2018/2019 


\section{KATA PENGANTAR}

Puji syukur atas kehadirat Allah Swt. Atas segala karunia dan nikmat yang diberikan sehingga kami dapat menyelesaikan makalah tentang Perbaikan Proses dengan tepat pada waktunya, tanpa ada halangan yang berarti, makalah ini disusun untuk memenuhi tugas mata kuliah Pemodelan Proses Bisnis.

Kami menyadari bahwa masih banyak kesalahan dalam penyusunan makalah ini, baik dari segi EYD, kosakata, tata bahasa, etika maupun isi. Oleh karna itu kami sangat mengharapkan kritik dan saran yang membangun dari pembaca sekalian untuk kami jadikan bahan evaluasi.

Akhir kata kami berharap semoga makalah ini bermanfaat bagi pembaca.

Bandar Lampung, 17 Desember 2018

Penyusun 


\section{DAFTAR ISI}

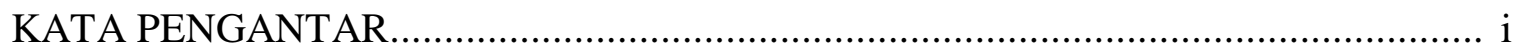

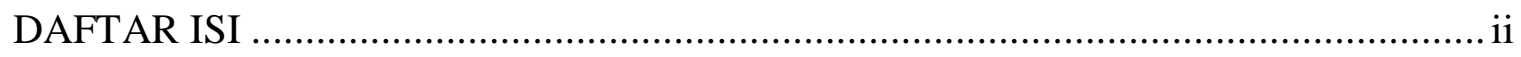

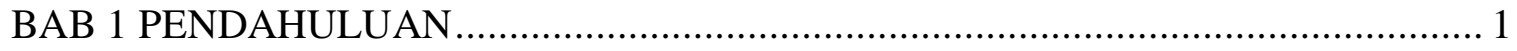

1.1 Latar Belakang ......................................................................... 1

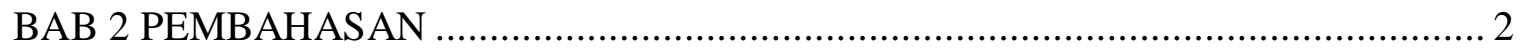

2.1 Perbaikan Proses ............................................................................... 2

2.2 Process Business Improvement (PBI) ............................................... 2

2.3 Process Business Reengineering (PBR) ............................................ 7

2.4 Process Business Inovation (PBI) .................................................... 10

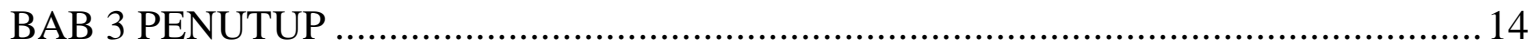

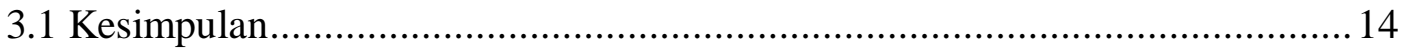

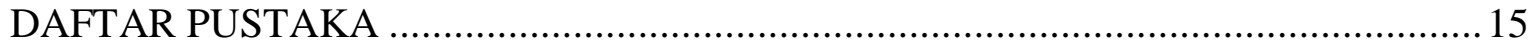




\section{BAB I \\ PENDAHULUAN}

\subsection{Latar Belakang}

Banyak orang beranggapan bahwa menciptakan ide-ide baru merupakan awal dari proses inovasi, padahal sebenarnya tidak juga. Menurut Longdon Morris, ide-ide baru justru muncul ditengah-tengah proses yang saat ini berlangsung. Menurutnya, dengan fokus pada perbaikan proses, maka inovasi itu akan muncul.

Secara historis proses kerja berfokus pada peningkatan efisisensi, waktu siklus, kualitas, atau biaya proses tertentu. Banyak dari upaya ini diharapkan dapat memberikan manfaat yang signifikan. Namun, ada aspek lain dari proses yang bias dibilang "jarang" digunakan, padahal sangat berpotensi besar meningkatkan kinerja perusahaan secara keseluruhan.

Proses merupakan aktualisasi dari strategi. Artinya, proses adalah cara-cara yang unik bagaiman perusahaan mencoba menciptakan produk yang berharga bagi pelanggan dan itu tercantum dari proses yang berlangsung sehari-hari. Strategi Brainstorming dinilai tidak lagi diperlukan, sehingga perusahaan bias focus pada bagaimana proses yang lebih mendetail bisa diukur dan berorientasi pada perbaikan proses terus menerus. Sehingga bias menghasilkan produk dan pengalaman yang lebih baik dari apa yang sudah tersedia dipasar. 


\section{BAB II \\ PEMBAHASAN}

\subsection{Perbaikan Proses}

Perbaikan proses adalah fase paling kreatif dari proyek proses engineering. Perbaikan proses akan mengevaluasi ide-ide alternatif dan 'menggerakkan' organisasi ke sesuatu yang baru atau berebeda. Semua informasi yang tersedia dari proses yang ada saat ini. Untuk meningkatkan proses bisnis sebuah organisasi, dibutuhkan pengalaman proyek proses engineering yang komprensif.

\subsection{Process Business Improvement (PBI)}

Proses Bisnis Improvement merupakan aktivitas yang memberikan nilai tambah (VA) untuk mengubah input menjadi output baik itu berupa barang atau jasa kepada customer dengan mengkombinasikan orang, metode, dan tools yang digunakan. Dibutuhkan penyempurnaan dalam proses dalam bisnis jika ingin memaksimalkan performance perusahaan.

Proses Bisnis Improvement harus dilakukan dengan berbagai alasan terutama yang diharapkan dari penggunaan Proses Bisnis Improvement (BPI) adalah analisis proses bisnis yang saat ini berjalan serta penyempurnaan future business process yang selaras dengan kebutuhan dan memaksimalkan keunggulan teknologi informasi.Tentunya sebelum melakukan pengkombinasian metode, tools dan orang diperlukan analisa yang mendalam agar pembisnis terutama StartUp dapat melihat kelebihan dan kekurangan analisis untuk kebutuhan Proses Bisnis Improvement.

Proses Bisnis Improvement (BPI), merupakan metodoliogi perencanaan dalam pengoperasian proses bisnis ataupun keterampilan karyawan yang dapat ditingkatkan agar lebih baik sehingga dapat mendorong prosedur, alur kerja yang lebih efisien dan efektif bagi pertumbuhan bisnis secara keseluruhan. Proses ini juga dapat disebut sebagai proses perbaikan fungsional yang dapat meningkatkan proses bisnis dalam satu perusahaan. Tujuan dari Proses Bisnis Improvement (BPI) adalah untuk mengeleminasi kesalahan-kesalahan, memberikan 
perusahaan keuntungan yang kompetitif dengan peningkatan proses bisnis, memenuhi permintaan pelanggan dan tujuan bisnis yang lebih efektif.

\section{A. Fase-fase Process Business Improvement :}

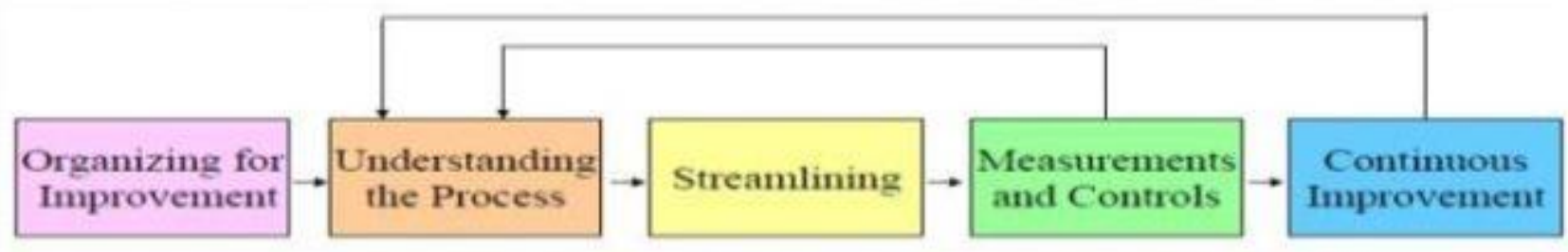

\section{Langkah ke-1 : Mengoranisir Perbaikan}

Mengorganisir perbaikan adalah pengoranisir perbaikan yang betujuan untuk mengelola proses bisnis internal maupun eksternal untuk menjadi lebih baik dalam suatu organisasi seperti berikut dibawah ini :

1. Pemilihan Process Owner

2. Mendefinisikan batas-batas awal perbaikan

3. Pembentukan dan pelatihan tim perbikan proses

4. Mengembangkan model perbaikan

5. Menetapkan ukuran-ukuran keberhasilan

\section{Langkah ke-2 : Pemahaman Proses}

Pemahaman proses dilakukan untuk mencapai pemahan seluruh dimensi yang ada di dalam proses bisnis yang berlangsung dalam organisasi sehingga proses yang berjalan jelas dan dimengerti oleh masing-masing dimensi fungsional dai arus proses maupun prosedur yang ada didalamnya.

1. Membuat bagan alir proses

2. Hubungan-hubungan dengan sebuah proses yang berjalan

3. Melakukan analisa waktu proses

4. Pelaksanaan perbaikan yang cepat

5. Pengaturan proses dan prosedur

\section{Langkah ke-3 : Penyederhanaan Proses}

Penyederhanaan proses adalah proses yang dilakukan untuk menyederhanakan proses dengan mengurangi waktu proses, menstandarisasi maupun memperbaharui proses yang semuanya bertujuan untuk memperbaiki efisiensi, efektivitas, dan adaptabilitas dari proses yang semuanya bertujuan untuk memperbaiki efisiensi,efektivitas, dan adaptabilitas dari proses bisnis yang berjalan.

1. Menyederhanakan proses

2. Pemilihan proses yang dikehendaki

3. Mengurangi birokrasi

4. Meng-upgrade peralatan 
5. Standarisasi proses

6. Mengurangi waktu proses

\section{Langkah ke-4 : Pengukuran dan Kontrol}

Pengukuran dan pengontrolan proses bisnis dilakukan untuk mengontrol jalannya proses bisnis dengan melakukan pemeriksaan dan pengukuran terhadap prediksi target yang ingin dicapai oleh organisasi.

1. Mengembakan pengukuran proses dan target yang dicapai

2. Menyediakan system umpan balik

3. Melakukan pemeriksaan proses secara berkala

\section{Langkah ke-5 : Perbaikan Berkelanjutan}

Perbaikan berkelanjutan dilakukan dengan tahapan dibawah ini dengan tujuan adalah untuk mencapai pengimplementasian proses perbaikan selanjutnya dengan berbagai proses seperti perubahan, menghapus, menambahkan proses, dan sebagainya.

1. Mengevaliasuasi dampak perubahasan terhadap bisnis dan pelanggan

2. Mengkualififikasi proses

3. Mencari dan menghilangkan masalah proses

4. Studi banding proses

5. Melihat kembali kualifikasi secara berkala

Cycle time merupakan siklus waktu yang digunakan dalam menghasilkan sebuah output dari input yang diberikan yang mana siklus waktu ini dapat menghambat efisiensi dan efektivitas proses bisnis perusahaan sehingga terdapat 3 cara untuk memperbaiki siklus waktu yang berjalan di dalam perusahaan yakni :

1. Eliminasi Kegiatan Non Value added (NVA). NVA merupakan aktivitas dari suatu proses bisnis yang tidak memberikan keuntungan dan nilai yang berarti kepada pelanggan maupun dalam proses bisnis sehingga dengan melakukan pengeliminasian aktivitas ini dapat memberikan efisiensi waktu pada proses bisnis organisasi. contoh: Redundant inspections, Filling in forms, Rework, Excessive transit, Waiting, Storage.

2. Meminimalisir kegiatan Business Value Added (BVA). BVA merupakan aktivitasaktivitas dari suatu proses bisnis yang tidak memberikan nilai tambah bagi hasil dari proses secara langsung, tetapi aktivitas ini diperlukan dalam proses bisnis sebagai pendukung untuk proses bisnis lainnya sehingga dengan adanya aktivitas ini dapat membantu proses menjadi lebih efektif namun aktivitas ini tidak dianjurkan untuk berlebihan sehingga membutuhkan pengurangan pada proses ini. contoh: Scheduling, Marketing, planning,Auditing.

3. Sederhanakan kegiatan Real Value Added (RVA). RVA mencakup proses penting yang mengubah input menjadi output yang diperlukan untuk memenuhi kepuasan pelanggan sehingga proses ini menjadi sangat penting namun semakin sederhana aktivitas ini 
semakin baik dalam keefektivitasan dan keefisiensian siklus waktu. contoh : Product development, Material procurement.

\section{B. Model Proses Bisnis}

Pemodelan proses bisnis/business process model adalah lintas fungsional, biasanya penggabungan pekerjaan dan dokumentasi lebih dari satu departemen dalam sebuah organisasi atau perusahaan. Secara implisit berfokus pada sebuah proses, tindakan dan kegiatan (Job), sumber daya (Resource) yang digambarkan dalam PPB menunjukkan bagaimana hal tersebut akan diproses.

Secara sederhana business process model ini dapat dipetakan melalui Value Stream Mapping (VSM) atau dapat digambarkan secara detail seperti gambar di bawah :

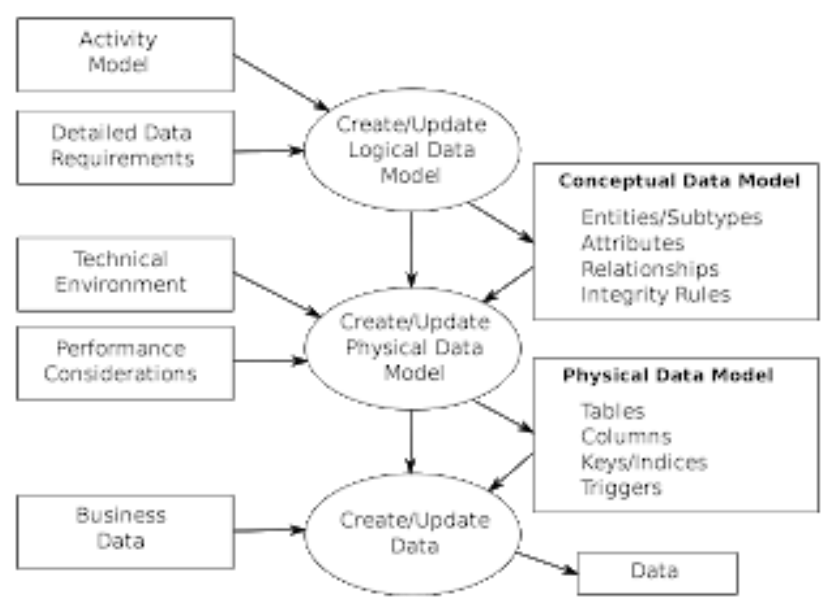

Untuk melakukan perbaikan proses bisnis yang perlu dilakukan adalah mengetahui feedback dari 
pelanggan untuk mengukur tingkat kepuasan layanan maupun produk yang di hasilkan oleh perusahaan.

Tujuan dari model ini adalah untuk menggambarkan supplier, proses input, proses output, proses customer, dan customer dengan output lain yang terkait serta ditunjukan feedback atau umpan balik dari customer.

Proses bisnis terdiri dari:

- Proses bisnis inti atau utama (core process), Proses-proses yang diselenggarakan untuk melayani pengguna jasa/produk.

- Proses bisnis pendukung (supporting process), Proses-proses yang diselenggarakan untuk melayani pelanggan internal yaitu karyawan. Proses ini bersifat mendukung proses bisnis inti atau utama.

Oleh karena itu mengapa untuk melakukan perbaikan proses bisnis berdasarkan kepuasan costumer, StartUp maupun pembisnis harus memahami Definisi Value Stream Mapping dan Pelaksanaannya.

Adapaun tujuan perlu adanya pemodelan proses bisnis ini adalah untuk menggambarkan proses yang lengkap, memungkinkan semua anggota perusahaan dari berbagai level kedudukan dapat meningkatkan aliran proses.

Tujuan utama dalam melakukan proses model bisnis adalah:

- Meningkatkan Nilai tambah Pelanggan (Value Added).

- Mengurangi biaya produksi perusahaan dengan menghilangkan pemborosan.

- Diharapkan dapat terciptanya peningkatan produktivitas pada keuntungan bagi semua pihak.

\section{Contoh Studi Kasus}

Seorang manajer produksi pada perusahaan botol yang bernama Rayarka, sedang termenung di meja kerjanya memikirkan masalah terkait meningkatnya biaya produksi dan menurunnya kualitas produksi khususnya pada produksi botol obat. Rayarka baru bekerja satu minggu sebagai manajer produksi menggantikan manajer sebelumnya. Ia diminta oleh manajemen untuk melakukan perbaikan di departemennya, yang bertujuan untuk meningkatkan kualitas dari proses produksi botol obat. Perlunya perbaikan proses produksi, didasari oleh banyaknya pesanan pelanggan yang tidak sesuai dengan keinginan pelanggan terutama pada spesifikasi botol obat yang dipesan dan waktu penyelesaian produksi.

Ketika perusahaan Rayarka bekerja masih sebagai produsen tunggal untuk botol obat, tidak banyak pelanggan yang mengeluh. Namun ketika sudah mulai banyak pesaing, perusahaan mulai mendapatkan banyak keluhan dari pelanggan karena kualitas produk yang dihasilkan tidak lebih 
baik dibandingkan pesaing. Untuk mencapai sasaran strategis perusahaan, yaitu menurunkan jumlah keluhan, Rayarka diberi tugas untuk meningkatkan kualitas produk. Rayarka bersama tim produksi mencoba untuk memetakan proses bisnis yang berjalan saat ini dan mengidentifikasi keinginan dari pelanggan internal serta kebijakan yang ada di perusahaan. Rayarka sangat kaget melihat proses produksi yang sangat tidak teratur, dan ternyata memang banyak permintaan pelanggan yang tidak sesuai dengan hasil produksi botol yang berjalan saat ini.

Setelah Rayarka beserta tim produksi melakukan pemetaan proses produksi sebelumnya, mengidentifikasi dan mengukur keinginan pelanggan, mereka mulai mencoba mengidentifikasi hal-hal apa saja yang dapat menghambat (waste) proses produksi. Rayarka dan tim melihat ada beberapa waste pada proses produksi seperti, waktu tunggu yang cukup lama dari proses menyiapkan bahan baku sampai proses cetak botol, jumlah botol yang gagal produksi (defect)hampir seperempatnya dari permintaan yang berakibat pada tingginya biaya yang dibutuhkan dalam proses produksi.

Setelah mengidentifikasi akar permasalahan yang terjadi pada proses produksi, Rayarka mulai melakukan perbaikan pada proses tersebut dan membuat prosedur standar dari proses yang telah diperbaiki. Langkah Rayarka tidak berhenti sampai membuat prosedur standar saja, ia berencana melakukan pemantauan secara berkala setiap 3 bulan dari proses produksi yang telah diperbaiki.

Ilustrasi cerita di atas menggambarkan contoh kasus mengenai pentingnya perbaikan proses untuk meningkatkan kualitas dan efisiensi biaya di suatu departemen. Pada kenyataannya di dalam organisasi yang perlu diperbaiki tidak hanya di departemen produksi saja, seluruh departemen di organisasi juga memerlukan perbaikan proses secara parsial masing-masing departemen, maupun perbaikan proses yang terintegrasi di organisasi.

Contohnya seperti, Departemen sumber daya manusia memerlukan perbaikan dalam proses penerimaan pegawai, Departemen keuangan memerlukan perbaikan dalam proses pencairan dana, Departemen purchasing memerlukan perbaikan dalam bidang kecepatan dan keakuratan pengadaan barang dan sebagainya. Tantangan untuk melakukan perbaikan proses, diperlukan kompetensi yang biasanya lebih banyak dikuasai oleh orang-orang di departemen produksi. Tools untuk pengelolaan perbaikan juga lebih banyak dikenal dan dipelajari di departemen produksi, namun tidak mudah untuk di implementasikan diluar departemen produksi karena terlihat sangat teknis dan kompleks.

GML Performance Consulting telah memperkenalkan PMX atau Process Management Excellence, yaitu suatu alat yang digunakan untuk meningkatkan pengelolaan proses. Alat untuk meningkatkan kecepatan pelayanan, meningkatkan keakuratan kualitas, menurunkan biaya dengan metode Map (memetakan), Measure (Mengukur) dan Improve (memperbaiki) melalui tools yang mudah dipakai dan simulasi yang mudah dipahami. Semakin banyak orang di dalam organisasi 
yang memahami cara melakukan perbaikan proses, maka semakin mudah untuk melakukan peningkatan kualitas dari output yang dihasilkan dari suatu proses.

\subsection{Process Business Reengineering (PBR)}

Business Process Reengineering dikenal juga dengan istilah Business Process Redesign (Perancangan Ulang Proses Bisnis), Business Transformation, atau Business Process Change Management. Process Business Reengineering (PBR) dimulai sebagai teknik sektor privat untuk mendukung organisasi secara fundamental memikirkan kembali bagaimana mereka mengerjakan bisnis yang mampu meningkatkan jasa kepada pelanggan, memotong biaya operasional dan menjadi kompetitor kelas dunia. Kunci utama dalam perancangan ulang adalah pengembangan sistem informasi dan jaringan. Organisasi-organisasi besar semakin banyak menggunakan teknologi ini untuk lebih mendukung proses bisnis yang inovatif dibanding memperbaiki metode kerja pada saat yang sama.

Re-engineering (rekayasa ulang) adalah dasar dari perkembangan-perkembangan manajemen yang muncul belakangan ini. Tim lintas-fungsional (Cross-functional team), contohnya, telah banyak dikenal karena perannya dalam perancangan ulang tugas-tugas fungsional yang terpisah menjadi proses-proses lintas-fungsional yang lengkap.

Kunci utama dalam perancangan ulang proses bisnis adalah pengembangan sistem informasi dan jaringan. PBR mengubah 5 komponen dalam bisnis yaitu :

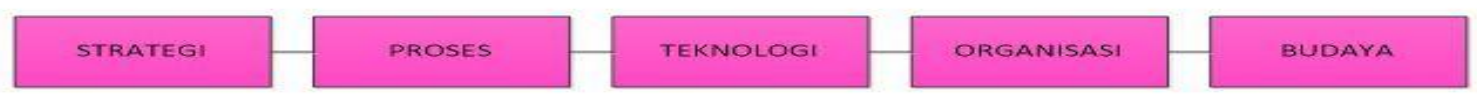

\section{A. Langkah-langkah dalam Process Bussiness Reengineering :}
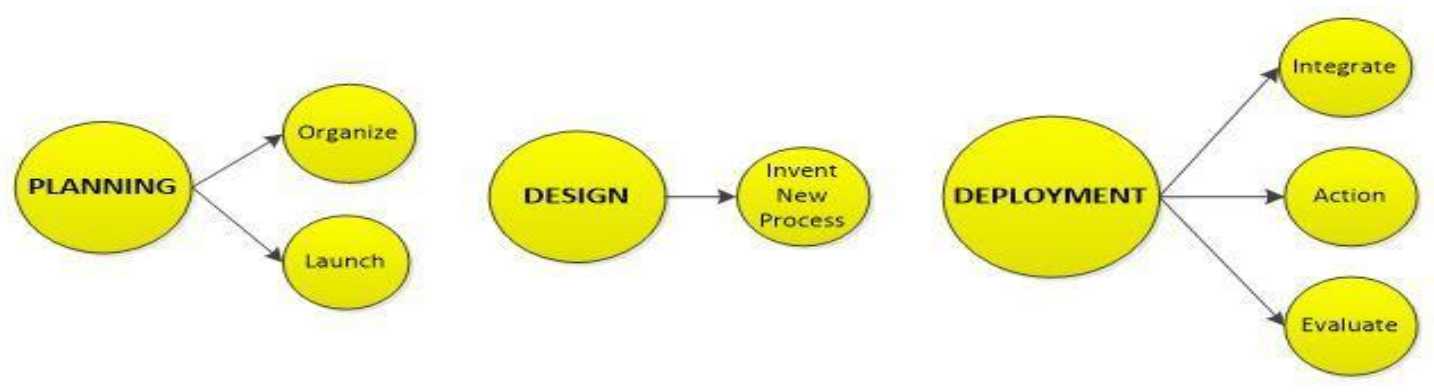

\section{Planning}

\section{Organize}

Menilai kemampuan dan kesiapan organisasi untuk menerima perubahan proses yang diharapkan. Kemudian mengidentifikasi proses-proses dalam organisasi serta menentukan core proses yang kritis. Mengukur efektivitas dan efisiensi dari setiap proses agar dapat menentukan prioritas perbaikan yang harus dilakukan. Setelah itu lakukan pengambilan 
keputusan untuk melakukan perbaikan berdasarkan faktor importance, opportunity, and feasibility.

\section{Launch}

Menunjuk tim proyek yang memiliki pengetahuan tentang proses bisnis dan reengineering. Kemudian mempelajari lingkungan internal ataupun eksternal yang akan mempengaruhi kesuksesan dari proyek yang akan dijalankan.

\section{Design}

\section{$>$ Invent a New Process}

Menghilangkan semua aturan dan mendefinisikan proses ideal yang akan dijalankan, kemudian mengembangkan beberapa alternative menggunakan proses benchmarking untuk menentukan metode yang terbaik. Setelah itu yang harus dilakukan adalah uji konsekuensi dengan menggunakan design secara radikal untuk mendapatkan solusi terbaik.

\section{Deployment}

\section{$>$ Integrate}

Mengkomunikasikan rencana yang telah direkomendasikan kepada stakeholders serta merefleksikan perbaikan proses bisnis dalam tujuan organisasi.

\section{Action}

Menguji proses baru agar mengetahui masalah-masalah yang akan terjadi kemudian menghilangkan masalah-msalah tersebut. Kemudian menetapkan penugasan tanggung jawab, jadwal, dan prioritas implementasi serta memperbaharui dokumentasi.

\section{$>$ Evaluate}

Mengontrol implementasi kemudian memperbaiki masalah-masalah yang ada dan memberikan penghargaan kepada tim yang telah berkontribusi serta melakukan perbaikan lebih lanjut terhadap proses yang baru.

\section{B. Contoh Studi Kasus}

Permata Guest House Semarang merupakan usaha bisnis yang bergerak di bidang jasa penginapan. Perkembangan bisnis Permata Guest House yang pesat ini tidak disertai dengan penataan dan pengelolaan proses bisnis (Business Process) yang memadai, akibatnya banyak keluhan dari stakeholder, yaitu dari pelanggan (customer), dan kalangan internal karyawan. Key Performance Indicator (KPI) yang digunakan dalam penelitian terhadap Permata Guest House ini adalah KPI yang diturunkan dari Critical Success Factor (CSF). Pengukuran kinerja dilakukan berdasarkan indikator performansi (Performance Indicator).

\section{Analisis Proses Bisnis}

Metode yang digunakan untuk melakukan perencanaan ulang yaitu dengan Process Business Reengineering (PBR). Metode ini dipilih karena PBR merupakan suatu proses perancangan kembali proses bisnis untuk memperoleh perbaikan atas performansi perusahaan. 
Adanya perbaikan yang dilakukan meliputi aktivitas dari proses bisnis reception yang mencakup proses bisnis reservasi dan proses bisnis penitipan barang. Dari perbaikan aktivitas pada reception ini berpengaruh juga pada proses bisnis housekeeping, yaitu pada sistem reservasi dan aktivitas pelaporan barang kerusakan kepada front office. Selain perbaikan pada proses bisnis, perbaikan ini juga dilakukan pada arah organisasi yang sebelumnya belum dimiliki perusahaan, yaitu penyusunan visi misi perusahaan, struktur organisasi, job description, dan SOP.

\section{Analisis Process Business Reengineering}

Sebelum memasuki tahap PBR, untuk menunjukkan permasalahan pada proses bisnis yang terjadi dalam usaha penginapan ini maka dilakukan pemetaan alur proses bisnis awal. Dari pemetaan alur proses bisnis awal ini didapatkan gambaran proses bisnis secara umum. Setelah didapatkan proses bisnis awal ini, dilakukan tahap selanjutnya yaitu menentukan Critical Succes Factor (CSF) dari usaha penginapan Permata Guest House. Dari penentuan CSF diperoleh CSF dari Permata Guest House adalah fasilitas, sumber daya manusia, organisasi, dan customer. Untuk memberitahukan kinerja perusahaan dalam mencapai faktor-faktor keberhasilan tersebut, CSF memerlukan suatu ukuran atau indicator yang disebut sebagai KPI (Key Performance Indicator).

Tahap selanjutnya adalah mengidentifikasi model kinerja proses bisnis yang didapatkan dari key performance indicator. Hasil dari identifikasi ini didapatkan bahwa terdapat selisih antara hasil yang dicapai saat ini dengan target yang diinginkan perusahaan dalam kurun waktu 1 tahun. Dengan demikian akan dilakukan tahap selanjutnya untuk meminimalisasi selisih yang terjadi, agar sesuai dengan target yang diinginkan yaitu dengan melakukan PBR. Pada rekayasa ulang proses bisnis tahapan yang dilakukan terdiri atas $3 \mathrm{R}$ yaitu sebagai rethink, redesign, dan retool.

\section{E. Analisis Pembakuan Usulan Proses Bisnis}

Analisis pembakuan usulan proses bisnis ini meliputi proses bisnis reception yang terdiri dari sistem reservasi dan penitipan barang dan proses bisnis housekeeping yang terdiri dari pengecekan kebersihan, kelengkapan kamar, dan pelaporan kerusakan barang.

\section{F. Analisis Perbaikan Organisasi}

Pada tahap perbaikan organisasi yang telah disusun adanya arah organisasi yaitu dari penyusunan visi dan misi perusahaan, penyusunan struktur organisasi yang mencakup elemen penting dalam mendesain struktur organisasi yang terdiri dari spesialisasi pekerjaan, departmentalisasi, rantai perintah, rentang kendali, sentralisasi, desentralisasi. Selain itu juga telah dijelaskan job 
description dari masing-masing bagian yang berdasarkan struktur organisasi, serta penyusunan prosedur standar kerja.

\section{G. Kesimpulan}

Faktor-faktor yang menyebabkan ketidakefisienan proses bisnis Permata Guest House adalah fasilitas, sumber daya manusia, organisasi, dan customer yang telah diidentifikasikan lebih rinci berdasarkan tiap variable indikator performansi. Faktor yang mempengaruhi yaitu fasilitas yang dimiliki perusahaan, sumber daya manusia yang meliputi moral keja dan loyalitas, keramah tamahan, penampilan dan sikap, dan program training \& development. Faktor organisasi meliputi visi dan misi, struktur organisasi, job description dan SOP. Faktor customer meliputi kepuasan layanan, lokasi, harga dan customer relationship.

Salah satu usulan untuk meningkatkan kinerja adalah dengan merancang ulang proses bisnis pada Permata Guest House dengan metode Process Business Reengineering (PBR) dengan memperbaiki proses bisnis yang dinilai berpengaruh terhadap kinerja perusahaan. Perbaikan meliputi perbaikan atas proses bisnis awal dan menyusun prosedur berdasarkan prosedur bisnis usulan.

Dari hasil rekayasa ulang proses bisnis didapatkan penysunan Standar Operating Procedure pelaksanaan kerja karyawan yang meliputi pada proses bisnis reception yang terdiri dari sistem reservasi dan penitipan barang, dan proses bisnis housekeeping yang terdiri dari proses pengecekan kamar dan pelaporan kerusakan barang.

\subsection{Process Business Innovation (PBI)}

Inovasi bisnis adalah perubahan yang terjadi dalam suatu perusahaan dan merupakan salah satu cara untuk mengembangkan sebuah perusahaan menuju arah perubahan yang lebih baik. Inovasi bisnis menjadi sebuah keharusan bagi setiap jenis usaha antara lain: perusahaan dalam skala kecil, skala menengah dan skala besar.

Pengertian Inovasi Menurut beberapa Ahli :

\section{Everett M. Rogers}

Menurut Everett M. Rogers, pengertian inovasi adalah suatu ide, gagasan, ojek, dan praktik yang dilandasi dan diterima sebagai suatu hal yang baru oleh seseorang atau pun kelompok tertentu untuk diaplikasikan atau pun diadopsi.

\section{Kuniyoshi Urabe}

Menurut Kuniyoshi Urabe, pengertian inovasi adalah segala hal yang dihasilkan melalui suatu proses yang panjang dan kumulatif, meliputi banyak proses pengambilan keputusan, mulai dari penemuan gagasan hingga ke implementasian nya di pasar "Proses bisnis terjadi dalam setiap lini operasi dan dalam setiap fungsi dalam perusahaan. Inovasi dalam proses bisnis tidak harus selalu besar. Inovasi dalam hal-hal kecil namun memiliki impact yang besar juga penting dilakukan, misalnya birokrasi perusahaan yang 
dibuat menjadi lebih simpel. Langkah-langkah yang panjang harus dibuat pendek. Selain itu, kita juga harus dapat memberikan apa yang dijanjikan kepada konsumen dengan tepat waktu. Secara internal, inovasi proses bisnis meningkatkan efektifitas dan efisiensi perusahaan, sedangkan secara eksternal dapat mengoptimalkan kepuasan pelanggan. Dengan demikian, loyalitas terhadap perusahaan juga dapat dibangun dengan baik.”

\section{A. Tujuan Inovasi}

\section{Meningkatkan Kualitas}

Secara umum, tujuan inovasi di berbagai bidang adalah untuk meningkatkan kualitas dan juga nilai sesuatu hal yang sudah ada, baik itu produk atau layanan. Dengan adanya inovasi terbaru, diharapkan produk-produk tersebut memiliki keunggulan dan manfaat yang lebih bernilai dari sebelumnya.

\section{Mengurangi Biaya}

Inovasi juga bertujuan untuk membantu mengurangi biaya, khususnya biaya tenaga kerja. Sebagai contoh, sekarang ini banyak diciptakan mesin atau peralatan yang dapat menggantikan tenaga manusia dalam proses produksi. Dengan adanya mesin dan peralatan tersebut maka biaya tenaga kerja untuk produksi akan semakin berkurang. Selain itu, penggunaan mesin dan peralatan pada proses produksi barang/ jasa tertentu akan menghasilkan kinerja lebih baik.

\section{Menciptakan Pasar Baru}

Dengan adanya produk yang lebih bernilai tinggi sebagai hasil dari inovasi, maka hal ini akan menciptakan pasar baru di masyarakat.

\section{Memperluas Jangkauan Produk}

Salah satu contohnya dapat kita lihat dari bisnis e-commerce seperti saat ini. Para pengusaha memperluas jangkauan produk mereka dengan memanfaatkan internet yang dapat diakses lebih banyak calon konsumen potensial.

\section{Mengganti Produk/Layanan}

Inovasi juga bertujuan untuk mengganti produk atau layanan yang dianggap kurang efektif/ efisien. Salah satunya dapat kita lihat inovasi yang terjadi pada mesin sepeda motor yang sekarang lebih hemat bensin.

\section{Mengurangi Konsumsi Energi}

Manusia selalu ingin menghemat penggunaan energi, itulah sebabnya ada banyak sekali inovasi yang dilakukan manusia. Salah satunya adalah adanya sumber energi terbarukan 
yang memanfaatkan alam, misalnya tenaga surya, angin, dan air, sebagai sumber energi listrik.

\section{B. Ciri-Ciri Inovasi}

Tidak semua ide atau gagasan dapat dikategorikan sebagai inovasi. Adapun ciri-ciri inovasi adalah sebagai berikut:

- Memiliki ciri khas, dengan kata lain suatu ide dapat dikategorikan dalam inovasi bila memiliki ciri khas yang spesifik.

- Merupakan ide baru, yaitu suatu ide yang belum pernah dipublikasi atau diungkapkan oleh orang lain sebelumnya.

- Dilakukan secara terencana, suatu ide dapat dikategorikan sebagai suatu inovasi bila dilakukan dengan sengaja dan terencana dalam pengembangannya.

- Memiliki tujuan, masih berhubungan dengan poin sebelumnya, inovasi merupakan ide yang dieksekusi secara sengaja dan terencana dengan tujuan tertentu

\section{Contoh studi kasus}

Go-Jek merupajkan sebuah perusahaan jasa, maka Supply Chain Management yang dilakukan Go-Jek merupakan suatu konsep manajemen dimana perusahaan berusaha memanfaatkan teknologi internet untuk mengintegrasikan seluruh mitra kerja perusahaan, baik para driver (pekerja), konsumen, dan juga para stakeholder yang berhubungan dalam kegiatan transaksi. Sistem akuntansi dari Go-Jek tersusun dari diantaranya fasilitas order processing yaitu fasilitas yang memungkinkan untuk konsumen melakukan pemesanan jasa, kemudian data yang telah diperoleh dari form yang tertera akan menentukan jumlah pembayaran. Jumlah pembayaran tersebut termasuk ke dalam fasilitas billing yang kemudian akan dibukukan menjadi general ledger. Bukti dari pembayaran yang telah dilakukan oleh konsumen akan tertera pada cash receipt yang kemudian akan terakumulasikan pada general ledger. Pemesanan yang dilakukan oleh konsumen terhadap mitra dari Go-Jek akan masuk ke dalam sistem cash disbursement-account payable tergantung kepada jenis pembagian untung yang telah disepakati oleh pihak Go-Jek dan mitra yang bersangkutan. Pembagian keuntungan yang telah masuk ke dalam perjanjian kedua belah pihak akan termasuk ke dalam sistem general ledger Go-Jek.

Hal yang merupakan perbedaan dari Go-Jek dan perusahaan pelayanan jasa lainnya terletak pada mekanisme pembayaran upah atau gaji dari driver. Pembagian upah terbagi menjadi $80 \%$ yang diberikan kepada driver dan $20 \%$ yang masuk ke dalam keuntungan perusahaan. Upah yang merupakan hak driver dapat diperoleh secara harian atau bulanan tergantung kepada keinginan. Seluruh arus kas yang telah dicatat di general ledger akan dituang ke dalam financial reporting.

Dalam menggunakan layanan jasa Go-Jek konsumen diwajibkan melakukan top-up melalui bank yang telah bekerja samadengan minimal jumlah uang yang di top-up sebesar Rp 100.000,-. Selanjutnya uang yang telah masuk akan dicatat kedalam database perusahaan sesuai dengan akun pengguna. Go-Jek menggunakan aplikasi secara realtime dalam menghitung jumlah argo per 
transaksinya. Jumlah transaksi yang masuk akan diakumulasikan di dalam database dan secara langsung, uang yang telah di top-up akan terpotong secara otomatis sesuai dengan jumlah nominal transaksi. Selanjutnya, perusahaan akan langsung membagi pendapatan dengan driver sesuai kesepakatan presentase yakni $80 \%$ untuk pihak driver dan $20 \%$ untuk pihak perusahaan.

Hal tersebut dilakukaan karena Go-Jek tidak menerapkan sistem penggajian bulanan. Routing merupakan proses untuk memilih jalur ( $p a t h$ ) yang harus dilalui oleh paket untuk dapat sampai ke tujuan dari satu lokasi ke lokasi lain. Sedangkan shipping merupakan proses pengiriman barang secara fisik via darat, laut, atau udara yang membutuhkan proses routing Go-Jek dalam praksisnya sudah menggunakan asas e-businessdalam proses shipping dikarenakan dalam proses pemesanan layanan tersebut sudah berbasis teknologi informasi dalam bentuk smartphone. Sehingga konsumen dan pihak perusahaan dapat terintegrasi secara real-time dalam kegiatan transaksi tersebut. Sedangkan dalam proses routing tersebut perusahaan menggunakan teknologi GPS (Global Positioning System). Hal tersebut memberikan benefit pada berbagai pihak baik konsumen, driver, maupun perusahaan. 


\section{PENUTUP}

\subsection{Kesimpulan}

Dari penjelasan diatas kami dapat menyimpulkan bahwa Pemodelan Proses Bisnis yang membahas mengenai Perbaikan Proses, berarti dalam materi ini kita belajar untuk memperbaiki suatu proses yang dapat terjadi dalam bisnis. Bisnis dapat lebih bersaing dan menghasilkan profit lebih banyak, kenaikan produktifitas,menyediakan tingkat pelayanan konsumen yang lebih tinggi, memperoleh fleksibilitas lebih besar dalam penggunaan sumber daya, termasuj staff, merespon lebih cepat pada peluang baru, meningkatkan moral staffmelalui lingkungan kerja yang lebih baik, dan menjalankan teknologi yang lebih baru tanpa hambatan.

Demikianlah Makalah kami tentang Perbaikan Proses, tentunya masih banyak kekurangan dan kelemahannya, karna tebatasnya pengetahuan dan kurangnya referensi yang ada hubungannya dengan judul makalah ini. Kami mengucapkan mohon maaf yang sebesar besarnya apabila ada kesalahan ejaan dalam penulisan kata dan kalimat yang kurang jelas, kurang dimengerti, dan lugas. Kami ucapkan terima kasih. 


\section{DAFTAR PUSTAKA}

http://www.knowcap.co.id/perbaikan-proses-bisnis-yang-mendukung-peningkatan-kualitas-danefisiensi-biaya/

http://blogcoretangw.blogspot.com/2017/11/perbaikan-proses-bisnisbusiness-process.html?m=1 https://id.wikipedia.org/wiki/Business Process Reengineering

https://industritelkomgambris04.wordpress.com/2014/05/30/136/

https://milaminora.wordpress.com/2016/02/13/sistem-informasi-manajemen-studi-kasus-go-jek$\underline{21}$

https://books.google.co.id/books?id=SR9bDwAAQBAJ\&pg=PA186\&dq=Proses+Bisnis+Inovas

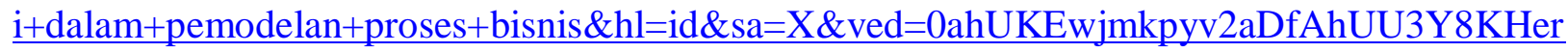
8DFgQ6AEILjAB\#v=onepage \&q=Proses\%20Bisnis\%20Inovasi\%20dalam\%20pemodelan\%20p roses $\% 20 \mathrm{bisnis} \& \mathrm{f}=$ false 


\section{PERTANYAAN DAN JAWABAN DARI KELOMPOK 1-10}

\section{KELOMPOK 1}

ALFINA DAMAYANTI (1711050020)

Pertanyaan :

Bagaimana jika dalam 1 perusahaan tidak dilakukan proses bisns yang maksimal, pasti terjadi kesalahan yang cukup fatal. Apa impact besarnya diperusahaan atau dikonsumennya?

Jawab

Tidak terlalu fatal, karena membuat perusahaan itu tidak berkembang hanya stuck dbisnis itu saja. Impact besarnya ke perusahaan adalah bangkrut karena tidak berkembang.

YULIANA (1711059012p)

Pertanyaan :

Dimengkoordinasikan perbaikan, apa maksud mengelola proses bisnis internal dan eksternal?

Jawab

Internal : Inovasi didalam terlebih dahulu, contohnya karyawan, staf perusahaan tersebut.

Eksternal : Mencari kepuasaan dari pelanggan/ Stakeholder.

\section{KELOMPOK 2}

\section{Pertanyaan :}

Jelaskan tentang HLL dan LLL!

Jawab

- HLL (High Level Languange) adalah program yang dekat dengan bahasa manusia.

-LLL (Low Level Languange) adalah program yang menggunakan bahasa mesin / kode, contoh kasusnya dalam sebuah perancangaan.

Pertanyaan :

Penjelasan tentang swimlane actor, proses, phases, simbol!

Jawab

Proses : Aqual proses

Actor : Orang yang melakukan proses

Phases : Tahapan / proses dari proyek

Simbol: Simbol fisik yang menggambarkan terjadinya sebuah tahapan dari proses.

\section{KELOMPOK 3}

\section{EMILIA FRISKA (1711050015)}

Pertanyaan :

Penjelasan proses pemodelan dan eksekusi proses bisnis dengan BPMN !

Jawab

Process monitoring, optimazation, auditor, analytics, integraton

- Dapat menggambarkan keseluruhan proses dari suatu diagram.

- Mampu memodelkan aliran pesan.

-Mampu memodelkan secara kuansial / feeedback. 
-Lebih mudah dipahami.

YULIANA (1711059012p)

Pertanyaan :

Apa kelebihan dari BPMN sampai perusahaan ingin menggunakan metode tersebut?

Jawab

Lebih mudah dalam penggunaannya

\section{SALWA BALQIS ( 1711050019)}

Pertanyaan :

Apa yang dimaksud dengan kebenaran tidak $100 \%$ ?

Jawab

Karena Rule Based System dibuat secara aturan, dipakai sesuai kebutuhan adanya.

\section{CHELVIN DEWANTORO (1711050036)}

Pertanyaan :

Pengertian Certical Success Factor?

Jawab

Sebagai ukuran keberhasilan yang ingin dicapai oleh proses bisnis tersebut/ekspetasi. Karena, perfomance yang sedang berjalan.

HARY AZHARI (1711050013)

Pertanyaan :

Penjelasan swimlane?

Jawab :

Swimlane adalah digambarkan dalam bentuk garis, pool lane : Bentuk.

NURUL (1711050091)

Pertanyaan :

Mengapa ASME ada dimetode ini?

Jawab

Karena organisasi mempunyai kode / standar ada suatu proses bisnis, proses tersendiri yaitu efisiensi waktu yang fungsinya sudah jarang digunakan karena bentuk bentuk tidak variatif.

M.RIZAKWAN HAFIZ (1711050045)

Pertanyaan :

Kapan kita menggunakan koreografi dan kolaborasi ?

Jawab

Koreografi : Penggunannya sesuai kebutuhan, info hasil / outputan.

Kolaborasi : Melihatkan 1 dan 2 entitasuntuk melakukan proses untuk tujuan yang sama.

\section{KELOMPOK 4}

\section{CHINTYA WULANDARI}

Pertanyaan :

Kendala apa saja yang ada pada 4 tahapan proses pada rekayasa ulang dan cara mengatasinya?

Jawab

Kendala nya :

- Tradisi, yang dihilangkan

-Penolakan,

-Persyaratan waktu, membuat proses

-Biaya yang agak mahal 
-Resiko, mendorong rekayasa ulang adanya resiko

-Skeptisisme, kurangnya kepercayaan diri

Cara Mengatasinya : Membujuk beberapa oknum yang menolak user membutuhkan adaptasi / beradaptasi dengan sistem proses tersebut.

\section{IKHSAN}

Pertanyaan :

Bagaimana cara kita untuk mengidentifikasi sebuah rekayasa proses bisnis? Apa perlu direkayasa ulang?

Jawab

Manjamen sudah memikirkan / mempeertimbangkan pasar dan jangka panjang. Ada untung dan rugi dalam perubahan proses bisnis.

\section{RIO}

Pertanyaan :

Prinsip / tata cara / saran?

Jawab

Prinsip / Tata Cara : Menetapkan 1 orang dalam proses bisnis

Point-point yang perlu diidentifikasi

-Tidak harus ada masalah dalam kebutuhan tetapi memang harus diupdate sesuai tenggang waktu / masa berlakunya sudah habis.

-Tentukan rekayasa dibutuhkan / dilakukan atau tidak

Acuan terpentingnya -> biaya, waktu, produk

\section{KELOMPOK 5}

Pertanyaan :

Apa maksud dari CRM?

Jawab :

CRM adalah sebuah pendekatan baru dalam mengelola hubungan komporasi dengan pelanggan pada level bisnis sehingga dapat memaksimumkan komunikasi dan pemasaran melalui pengelolaan berbagai kontak yang berbeda.

Pertanyaan :

Penjelasan tentang IDEF0?

Jawab

IDEF0 dikembangkan oleh Daugles. Para ahli dan softect merupakan pemodelan aktivtas yang didasarkan SADT "Stucture Analysis and Desain Teqnicque" untuk sistem IDEF0 dapat digunakan untuk menganalisa kinerja sistem.

Pertanyaan :

IDEF0 sebagai acuan bahasa pemodelan, ada tidak alternatif lain selain IDEF0?

Jawab

Yang menyatakan acuan IDEF0 NIST adalah teknologi national institut standar, ada alternatif lain yaitu waterfall, banyak contoh-contoh sistem progran sebagai acuan.

\section{KELOMPOK 6} FEBY SUMAYANDRA

Pertanyaan : 
Bagaimana IDEF0 dapat digunakan untuk menganalisa dan merekomendasikan peningkatan kinerja sistem?

Jawab

Dengan cara transparansi, visi dan misi, pencapaian target, menciptakan rasa nyaman pada karyawan.

RISWANDA

Pertanyaan :

Bagaimana cara menggunakan KPI dalam bisnis lokal ?

Jawab

Mempermudah / memungkinkan melakukan analisa.

KELOMPOK 7

PRATIWI NALITA (1711050055)

Pertanyaan :

Contoh BPI didunia perusahaan dan cara mengimplementasikannya?

Jawab ;

Dengan cara :

-Metodologi pendidikan proses bisnis

-Tahapan persiapan

-Identifikasi masalah

-Perumusan masalah dan tujuan penentuan

-Analisa dan interoretasi data

-Kesimpulan dan saran

Contoh : Amanda Brownis

CHELVIN DEWANTORO (1711050036)

Pertanyaan :

Dampak yang diharpkan yang dihasilkan dalam keberhasilan perusahaan?

Jawab

-Dapat mengurangi penundaan

-Dapat mengurangi eror

-Dapat memaksimalkan penempatan

-Dapat mudah digunakan

-Mendapatkan kepuasan pelanggan

-Dapat dengan mudah beradaptasi

-Dapat besaing keunggulan

\section{KELOMPOK 8}

M.FABBLY ABDURAHMAN (1711050052)

Pertanyaan :

Kelemahan BPMN

Jawab

1.Simbol-simbol BPMN terlalu complicated untuk diimplementasikan pada real transaksi di industry.

2.BPMN tidak bias menggambarkan hasil proses dan model resiko, sehingga Key Performance Indicator (KPI) tidak bias digambarkan menggunakan notasi BPMN. 
3.Tidak bias menggambarkan conceptual modeling business logic dan detail dari aktivitas.

\section{KELOMPOK 9}

SALWA BALQIS (1711050019)

Pertanyaan :

Organisasi apa yang dapat dinaungi oleh ASME?

Jawab

Standar ASME itu menerapkan bukan menaungi (melindungi)

\section{KELOMPOK 10}

Pertanyaan :

Kekurangan dari esia itu sendiri, dan menggunakan metode apa?

Jawab

Jadi esia belum memiliki sumber daya manusia yang berkualitas 